\title{
Oceanography, Science, and Academia Women Making a Difference
}

BY NANCY MARCUS

Oceanography is a multidisciplinary field offering a range of career opportunities for the diversified workforce that exists today. Professionals conducting research or teaching about the oceans pendix 4). These data are similar to other scientific fields (as shown in Table 1). Nevertheless, the field of oceanography has come a long way from the days when women weren't even allowed on board

\section{The representation of women in professional}

\section{positions in oceanography, particularly at the highest levels in academia is, however, still highly skewed.}

are employed in focused, research-oriented oceanographic institutions, and an array of academic institutions from Doctoral/Research Extensive universities to community colleges, industry, and government. The representation of women in professional positions in oceanography, particularly at the highest levels in academia is, however, still highly skewed (Table 1). For example, data collected from 86 universities and four-year colleges with ocean-related programs indicate that in 2002, women comprised 9 percent of the full professors, 18 percent of the associate professors, and 30 percent of the assistant professors (U.S. Commission on Ocean Policy, 2004, Ap- ships to conduct research. This article examines some of the factors affecting the participation of women in science, and particularly oceanography.

\section{PROGRAMS TO ATTRACT AND}

\section{RETAIN WOMEN IN SCIENCE}

During the past three decades, the number of young women earning bachelors degrees in math, science, and engineering has grown substantially and out paced young men (National Science Foundation, 1998, 2004). Nelson (2005) reports that in the year 2000, women received an impressive 47,48 , and 58 percent of the bachelors degrees awarded in chemistry, mathematics, and biol- ogy, respectively (Table 1). In ocean-related fields, women received 41 percent of the bachelor's degrees in Academic Year 2001 (Table 1). This is a substantial increase compared to 1967 when women received only 10 percent of the bachelor's degrees in Earth, ocean, and atmospheric sciences (National Science Foundation, 1998). I have no doubt that one reason for this improvement has been the establishment of specialized programs to encourage the participation and retention of women in math, science, and engineering disciplines.

Today, I am the Director of Florida State University's Women in Math, Science, and Engineering (WIMSE) program, a residentially based learning community for undergraduate women interested in pursuing a career in one of these fields (more information available at http://www.fsu.edu/ wimse/). Liv-

Nancy Marcus (marcus@ocean.fsu.edu), is Chair and Robert O. Lawton Distinguished Professor and Mary Sears Professor of Oceanography, Department of Oceanography, Florida State University, Tallahassee, FL, USA. 
ing learning communities have become quite common on the campuses of large universities, especially in the last decade. They are typically organized around a theme, and class sizes for students enrolled in the program are usually small, allowing for professors to use interactive and cooperative learning approaches in their teaching. Other common features of the programs, which are designed to attract and retain women in science, include research internships, exposure to female role models, and mentoring. Although we are only in the fourth year of our program, to date our WIMSE students have a higher retention rate in math, science, and engineering majors than their peers who live in the general residence halls or who live off-campus as first-year students (Marcus, unpublished data). In addition to residentially based programs, numerous colleges and universities offer other specialized programs to attract and retain women students in science, math, and engineering fields (e.g., the Women in Science and Engineering [WISE] programs at both the University of Washington [http://www. engr.washington.edu/wise/]; and at the State University of New York, Stony Brook [http://www.wise.sunysb.edu/]).

Despite the enthusiasm and interest in science expressed by women at the undergraduate level, the percentage of women that pursue graduate study declines as evidenced by the data shown in Table 1. This leak along the educational pipeline continues after graduation, though some scientific fields (e.g., engineering, physics, and astronomy) are doing a good job of hiring women in proportion to the number of women earning Ph.D.s (see Table 1). On the other hand, fields such as chemistry, math, biology, and oceanography could be doing a better job; it is evident that a pool of potential women candidates exists for postdoctoral and faculty positions in these fields. The lack of women could be due to various factors including not getting promoted and tenured and women choosing other professional opportunities.

\section{FLORIDA STATE UNIVERSITY TAKES ACTION}

Several senior women faculty, concerned that women were not being promoted and tenured at Florida State University (FSU) at rates comparable to men, urged the creation of a task force to study the issue, as other institutions such as the Massachusetts Institute of Technology and Princeton University had done in the last decade. Following a meeting with FSU's provost during the summer 2001, the Task Force on the Status of Women Faculty at Florida State University was established, and I was asked to be the chair (more information available at http://ocean.fsu.edu/ nancy/TaskForce/ index.htm).

The Task Force included faculty (women and men) from four colleges (Arts and Sciences, Social Sciences, Business, and Communication). Dr. Mary Stutzman, Director of the Survey Research Laboratory, College of Social Sciences and her staff, assisted us. After meeting several times to formulate an approach for our work, we convened small focus groups to identify issues of

Table 1. Percentage of Women at Various Stages in the Academic Pipeline for Selected Scientific, Mathematic, and Engineering Fields

\begin{tabular}{|c|c|c|c|c|c|}
\hline & $\begin{array}{c}\text { B.S. } \\
\text { degrees }\end{array}$ & $\begin{array}{l}\text { Ph.D. } \\
\text { degrees }\end{array}$ & $\begin{array}{l}\text { Assistant } \\
\text { Professors }\end{array}$ & $\begin{array}{l}\text { Associate } \\
\text { Professors }\end{array}$ & $\begin{array}{c}\text { Full } \\
\text { Professors }\end{array}$ \\
\hline Astronomy ${ }^{1}$ & 32.7 & 20.6 & 22.0 & 16.5 & 9.5 \\
\hline Civil Engineering ${ }^{1}$ & 24.5 & 18.7 & 22.3 & 11.5 & 3.5 \\
\hline Physics ${ }^{1}$ & 21.4 & 13.3 & 11.2 & 9.8 & 4.6 \\
\hline Chemistry $^{1}$ & 47.3 & 31.3 & 21.5 & 20.5 & 7.6 \\
\hline Mathematics $^{1}$ & 48.2 & 27.2 & 19.6 & 13.2 & 4.6 \\
\hline Biology ${ }^{1}$ & 58.4 & 44.7 & 30.2 & 24.9 & 14.8 \\
\hline Ocean-Related $^{2}$ & 41 & 37 & 30 & 18 & 9 \\
\hline Oceanography ${ }^{3}$ & & 39 & & & \\
\hline Marine Science $^{3}$ & & 58 & & & \\
\hline $\begin{array}{l}\text { Earth, Ocean, } \\
\text { Atmosphere }^{3}\end{array}$ & & 33 & & & \\
\hline
\end{tabular}

${ }^{1}$ Data from Nelson (2005).

${ }^{2}$ Data from Appendix 4, U.S. Commission on Ocean Policy (2004).

${ }^{3}$ Data from Hoffer et al. (2004). 
concern to all faculty. We then developed a written survey that was distributed to all tenure track faculty. Having only studied copepods for 25 years, I was not prepared for a study of humans and gained a new respect for this type of research! In addition to the survey, we queried the institution's databases to obtain information on the composition (rank, gender, and ethnicity) of the faculty dating back to 1996 , salary, and recipients of university awards and honors. We also examined the responses of FSU faculty to the University of California at Los Angeles's Higher Education Research Institute (UCLA/ HERI) national surveys that were conducted at FSU in 1995 and 2000. All of the information was collated into a written report that we issued in fall 2003. We also issued a companion document that summarized the major problems and suggested potential solutions. The report and summary document are available on the FSU's web site at http://survey.coss. fsu.edu/TaskForce/.

Despite a general perception that the representation of women in academia had improved, our data showed that the overall percentage of women on the FSU faculty in 2002 (29 percent) had hovered at that level for seven years. Almost a decade without improvement! Hence, the results of the Nelson (2005) study and the article in The Chronicle for Higher Education, "Where the Elite Teach, It's Still a Man's World" (Wilson, 2004) have not surprised me. Sadly, the situation at FSU is not unique for Doctoral/Research Extensive universities. Another article in this issue of Oceanography (O'Connell and Holmes) presents data for units (university departments and whole organizations dedicated to ocean science) in our field and the results are no different.
WHERE ARE THE WOMEN GOING?

The results of Robin Bell's study at Columbia University (see article this issue) indicate that some women who receive their doctoral degree from major geoscience programs choose not to apply for positions at comparable institutions. While I would like to see more women on the faculties of our Doctoral/Research Extensive universities, this may not happen until the academic culture undergoes change (see below for suggested changes). On the other hand, people who choose to apply the training in oceanography that they receive at a research institution in other educational settings should be valued and encouraged.

I was very disturbed and discouraged to read the commentary, "Ditch the Boyfriend" in the October 1, 2004 issue of The Chronicle for Higher Education. The author is anonymous, but apparently the recent recipient of a Ph.D. in oceanography. She reports the words of wisdom she was given by a senior faculty member in her department. If she wanted to do "real research" she should not have children and she should stay away from teaching jobs because that would be a waste of her talents. Apparently, it doesn't take too many other people like this senior faculty member to drive people away from careers in oceanography at research universities and into what has been dubbed the "alternative career tracks" of four-year colleges, government, or consulting. Unfortunately, we still equate "alternative" with "not good" or "failure." How lucky for the students at four-year colleges to learn from these bright women, as pointed out by Borst and O'Shea (2004).

The gain of these institutions is our loss. As a faculty member at a Doctoral/ Research Extensive university, I want to see more women faculty in my department and university because I think that our students—both women and menare short-changed by their absence, as evidenced by research. Trower and Chait (2002) reported that having more women faculty leads to greater success of women students in the future, for example, seeking advanced degrees. It is true that many more women attend coeducational institutions compared to women's colleges. However, if they attend a women's college (where the proportion of women on the faculty is greater than at coeducational institutions) they are much more likely to pursue an advanced degree than their counterparts at coeducational schools (Trower and Chait, 2002). According to the recent report by Hoffer et al. (2004), 70,368 of the students who received doctorates between 1999 and 2003 had received their bachelor's degree at a Doctoral/Research Extensive university, and 46 percent of these students were women. On the other hand, of the 17,102 students receiving doctorates had received their bachelor's degree from a baccalaureate liberal arts college, 55 percent of these students were women. In the baccalaureate liberal arts category, the top 20 producers accounted for 5,853 students receiving doctoral degrees, and of those students, 61 percent were women. Five of these top 20 baccalaureate liberal arts schools are women's colleges (Smith, Wellesley, Bryn Mawr, Barnard, and Mt. Holyoke). Even though the absolute numbers are smaller, if you attend a women's college, you are more likely to go on to obtain a doctorate than a woman at a coeducational institutional, large or small. 


\section{NEXT STEPS}

Now is the time for institutions categorized as Doctoral/Research Extensive universities and comparable institutions to take some bold steps and examine their academic culture.

- Policies on family leave need to be examined and more flexibility introduced into the tenure clock. However, Bhattacharjee (2004) reports that instituting policies allowing for stoppage of the tenure clock may not be sufficient because of the "fear factor." If there is a fear that stopping the tenure clock is viewed negatively by one's colleagues, then women and men may not take advantage of such an option.

- Potential bias in the review of tenure binders must be acknowledged and steps taken to improve the transparency of the process. A very novel approach to this problem is the ADEPT web-based tool developed at Georgia Institute of Technology under the auspices of the NSF ADVANCE program (http://www.adept.gatech.edu/ download.htm). The ADEPT instrument was developed "to assist users in identifying forms of bias in evaluation processes in order to achieve fair and objective evaluations." Attention to these issues will open the door for greater participation.

- Department chairs must take steps to protect new untenured faculty, especially women, from excessive committee assignments. Too often women become overburdened with service activities as institutions strive for gender balance on committees. The result is that women at the assistant professor level run the risk of not obtaining tenure and women at the higher ranks become burned out.

- Recognizing the accomplishments of faculty is another issue that deserves attention as it ultimately affects promotion and salary raises. Our study at FSU revealed that women faculty were not being nominated for key awards despite outstanding records of accomplishments. Administrators must take steps to ensure that all faculty deserving recognition are considered for awards. Alternatively, consideration should be given to including the possibility of self-nomination for certain awards and honors.

Our study showed that of the faculty who undertook administrative positions, a greater proportion of the women served in these positions as associate professors whereas the men in these administrative positions were generally full professors. The reason for this difference is most likely that institutions wanting to increase the number of women serving in administrative positions must expand the pool of potential candidates by including those at the rank of Associate Professor. While institutions are to be commended for recognizing the need for including women in administrative positions, there are several pitfalls, mostly for the women. Administrators holding the rank of Associate Professor generally will not have the breadth of experience with the operations of their institutions as their more senior colleagues, nor will they likely receive the same level of respect as a Full Professor holding their position-especially from another Full Professor! In addition, it is likely that those who become involved with administration as an associate professor delay their promotion to the rank of Full
Professor, and the danger exists that they will never be promoted. Although such people may go on to productive careers in administration, in all likelihood they cease being active faculty researchers and academic role models for young women. They are essentially lost from the academic pool before ever reaching the rank of Full Professor and represent another leak in the pipeline.

\section{OCEANOGRAPHY EDUCATION}

\section{AND THE ROLE OF WOMEN}

\section{OCEANOGRAPHERS}

The discipline of oceanography developed with a particularly strong, singleminded devotion to research. Reflecting back on my days at the Woods Hole Oceanographic Institution in the 1970s and 1980s, it appeared to me that most of my colleagues, particularly the senior scientists, cherished being able to devote essentially all of their time to research. Interestingly, Trower and Chait (2002) suggest that "single-minded devotion to professional pursuits" is a reason why greater diversity has not been achieved in our top academic institutions.

When I was President of the American Society of Limnology and Oceanography (ASLO) from 1995-1996, such single-minded devotion/attention to research was also evident in the mission of the society and other comparable scientific organizations. I sought to broaden the scope of the ASLO's mission to include a focus on education (after all many of the members held positions as university faculty where there was a responsibility to teach as well as be active in research), so I set this as one of my goals. We began by offering two workshops at the 1995 annual meeting 
in Reno, Nevada. One focused on the use of emerging computer technologies in undergraduate courses and the second led by Ms. Cheryl Dybas, focused on "alternative careers in the aquatic sciences" (Dybas, 1995). This was followed with more workshops and special sessions at subsequent annual meetings.

In 1997, a special section on education issues was incorporated into the ASLO Bulletin. In the mid-1990s, the National Science Foundation (NSF) and National Oceanic and Atmospheric Administration began promoting a number of science-related education initiatives and workshops. In 1998, after attending a one-week summer workshop on innovative approaches to teaching geoscience courses organized by Dr. Heather McDonald with support from NSF and the National Association of Geoscience Teachers (NAGT), I joined several of the attendees to offer a condensed version at the 1999 Aquatic Sciences meeting in Santa Fe, New Mexico. The workshop introduced us to experiential learning approaches, de-emphasized content, and focused on critical thinking and active learning. These are all things they never taught me as a graduate student! I started to think about new ways to organize the introductory oceanography course, which moved me away from traditional lecturing. The session in Santa Fe was well attended. So, what started as an afternoon panel discussion in 1995 with a few participants who were interested in discussing new approaches to teaching oceanography has now grown to several contributed oral and poster sessions (see schedule for the ASLO Aquatic Sciences Meeting 2005; http://www.aslo.org/ meetings/slc2005/) on innovations in teaching students at all educational levels about the oceans.

You might be wondering why I digressed into this discussion of education and ocean sciences. During the last two decades, most scientific professional societies have recognized the importance of having a mission that extends beyond research. Annual meetings and publications are now seen as opportunities to communicate the latest research discoveries to one's research colleagues as well as more general audiences. There is great interest in linking the latest discoveries in ocean science to teaching at all levels. Since the mid-1990s, Dr. McDonald and her colleagues have continued to offer workshops on innovative teaching methods and preparing for a career in the geosciences (http://serc.carleton. edu/NAGTWorkshops/about.html). Interestingly, women have represented 45 percent of the attendees ( $\mathrm{H}$. McDonald, personal communication) at these workshops, despite the fact that women constitute only $12.5 \%$ of the faculty in the geosciences (de Wet et al., 2002). I think it is likely that public support of ocean sciences would be far less than what it is today if oceanographic societies had not broadened their missions to encompass education and outreach. I will even speculate that the influx of women into oceanography that began in the late 1970s was responsible for this evolution.

In agreeing to write this article it was not my intent to criticize individuals, departments, or institutions. I will consider my time well spent if the topics highlighted in this issue of Oceanography generate discussion and, more importantly, solutions that lead to increased representation of women in the field and particularly on the faculties of Doctoral/ Research Extensive institutions. 四

\section{REFERENCES}

Bhattacharjee, Y. 2004. Family Matters: Stopping tenure clock may not be enough. Science 306: 2,031-2,033.

Borst, C. and D. O'Shea. 2004. Liberal-Arts Colleges and the Female Scientist. The Chronicle for Higher Education, March 5, 2004. Letter to the Editor.

De Wet, C.B., G.M. Ashley and D.P. Kegel. 2002. Biological Clocks and Tenure Timetables: Restructuring the Academic Timeline. GSA Today (Supp): 1-7.

Dybas, C. 1995. Alternative careers session attracts more than 100 attendees at the ASLO '95 meeting. ASLO Bulletin 4(3):6.

Hoffer, T.B., L. Selfa, V. Welch Jr., K. Williams, M. Hess, J. Friedman, S.C. Reyes, K. Webber, and I. Guzman-Barron. 2004. Doctorate Recipients from United States Universities: Summary Report 2003. National Opinion Research Center, Chicago. Note: The report gives the results of data collected in the Survey of Earned Doctorates, conducted for six Federal agencies, NSF, NIH, USED, NEH, USDA, and NASA by NORC.

National Science Foundation. 1998. Women, Minorities, and Persons With Disabilities in Science and Engineering: 1998. NSF 99-338. National Science Foundation, Arlington, VA. [Online] available at: http://www.nsf.gov/sbe/srs/ nsf99338/.

National Science Foundation. 2004. Women, Minorities, and Persons with Disabilities in Science and Engineering: 2004. NSF 04-317. National Science Foundation, Division of Science Resources Statistics, Arlington, VA. [Online] available at: http://www.nsf.gov/sbe/srs/wmpd. Note: Updated May 2004.

Nelson, D.J. 2005. A National Analysis of Diversity in Science and Engineering Faculties at Research Universities. [Online] available at: http:// cheminfo.chem.ou.edu/ djn/diversity/briefings/Diversity\%20Report\%20Final.pdf

The Chronicle for Higher Education. 2004. "Ditch the Boyfriend.” October 1, 2004. Commentary.

Trower, C.A. and R.P. Chait. 2002. Faculty diversity: Too little for too long. Harvard Magazine (March-April). [Online] available at: http:// www.harvard-magazine.com/on-line/030218. html.

U.S. Commission on Ocean Policy. 2004. Appendix 4. In: The Preliminary report of U.S. Commission on Ocean Policy. Washington, D.C. [Online] available at: http://oceancommission.gov/documents/prelimreport/append4.pdf.

Wilson, R. 2004. Where the elite teach, It's still a man's world. The Chronicle for Higher Education 51(15):A8. 